KS. LESZEK WILCZYŃSKI - POZNAŃ

\title{
NOWOCZESNY SYSTEM INFORMACYJNY W PRAKTYCE ARCHIWÓW KOŚCIELNYCH
}

\section{WSTEP}

Wykorzystanie dobrodziejstw Internetu od 1991 r. otworzyło możliwości m.in. szybkiego i łatwego dostępu do szczegółowej informacji o zbiorach archiwów. Dziś dzięki nowoczesnemu systemowi informacyjnemu jakim jest Internet bez trudu można dotrzeć do kilku tysięcy archiwów na całym świecie. Również archiwa kościelne zaczynają korzystać z tego sposobu prezentacji własnych zasobów.

Na 39 diecezji w Polsce własne archiwa (archi)diecezjalne posiada $27 \mathrm{z}$ nich: Białystok, Częstochowa, Drohiczyn, Gdańsk, Gniezno, Katowice, Kielce, Kraków, Lublin, Łomża, Łódź, Opole, Olsztyn, Pelplin, Płock, Poznań, Przemyśl, Rzeszów, Sandomierz, Siedlce, Szczecin, Tarnów, Warszawa, Włocławek, Wroclaw, Zamość, Zielona Góra. Z wymienionych placówek (archi)diecezjalnych własne strony lub podstrony internetowe $\mathrm{z}$ szerszymi informacjami posiadaja tylko archiwa archidiecezjalne w Gnieźnie, Katowicach, Poznaniu i diecezjalne w Łomży i Tarnowie. Dziçki stronom internetowym kwerendzista (posiadający dostęp do Internetu) może sprawdzić dane adresowe danego archiwum, godziny otwarcia, regulamin korzystania z pracowni i materiałów archiwalnych oraz zespoły archiwalne. W tym przypadku najwyraźniejszym pionierem z polskich archiwów kościelnych jest Archiwum Archidiecezjalne w Poznaniu.

\section{Przeglą STRON INTERNETOWYCH POLSKICII ARCIIWÓW (ARCHI)DIECEZJALNYCH}

Oto przegląd zakresu i zasobów informacyjnych, jakie można uzyskać na stronach internetowych archiwów archidiecezjalnych w Poznaniu, Gnieźnie i Katowicach oraz diecezjalnych w Lomży i Tarnowie. 


\section{Archiwum Archidiecezjalne w Poznaniu}

Najwiçcej danych o zasobach i naszej instytucji archiwalnej możemy uzyskać na stronie internetowej Archiwum Archidiecezjalnego w Poznaniu www.aap.poznan.pl. Serwis internetowy archiwum powstał w 1997 r. na serwerze, używanym wspólnie z Seminarium Towarzystwa Chrystusowego dla Polonii Zagranicznej. Sama sieć lokalna archiwum została już w 1996 r. podłączona światłowodem z Poznańskim Centrum Komputerowym, co pozwoliło na korzystanie z sieci internetowej, przygotowanej dla pracowników. Na powstałej stronie, oprócz historii i ogólnych wiadomości na temat zasobu, informacji administracyjnych (godziny urzędowania), umieszczono także nasz adres e-mail: sekretariat@aap.poznan.pl i pełny wykaz ksiąg metrykalnych, katolickich i ewangelickich, przechowywanych w Archiwum Archidiecezjalnym w Poznaniu.

Od 1998 r. w archiwum wykorzystuje siç program Archiwum 2000, który został zaprojektowany przez dr. Tomasza Paluszyńskiego z Katedry Archiwistyki UAM. Program ten pozwala na skomputeryzowanie wszystkich zbiorów archiwum.

Na początku 2000 roku - w 75 rocznicę powstania archiwum - chcąc ułatwić korzystanie z zasobów archiwum zeskanowano wszystkie inwentarze książkowe. Prace wykonała firma Mikrofilm-Center z Poznania. Teksty nagrano na ponad 40 plytach CD, zawierających ok. 24 tys. stron maszynopisu.

Z początkiem 2001 roku ogólnopolska firma ZIGZAG Internet Service Provider wykonała dla archiwum nową stronę internetową WWW (zmiana technologii i założeń wizualizacji). Do dziś można korzystać z informacji w czterech językach: polskim, francuskim, niemieckim i angielskim. Kwerendzista może zapoznać się zatem z lokalizacją archiwum (położenie na mapie Poznania, opis budynku i pomieszczeń, zdjęcia gmachu archiwum z lotu ptaka), najnowszymi komunikatami ( $w$ nich informacje na temat ostatnich publikacji z krótkimi ich opisami). Poza tym rozbudowano dwie podstrony, tzn. dotycząca archiwum i biblioteki (dawnej Biblioteki Archidiecezjalnej, której właścicielem jest obecnje Wydziat Teologiczny UAM a wcześniej Seminarium Duchowne), która korzysta z pomieszczeń archiwum.

Na podstronie archiwum można uzyskać podstawowe dane o historii instytucji oraz o wszystkich zbiorach. Informacje o zasobach archiwum ujçte zostały w dwóch plikach: Inwentarz (pliki graficzne) i Inwentarz (baza danych). Do utworzenia Inwentarza plików graficznych zeskanowano 24 tys. stron maszynopisu, dokonując kompresji do formatu GIF - maksymalnie zmniejszając ich objętość, co zagwarantowało szybki dostęp do dokumentu. Dla potrzeb utworzonej bazy danych eksportowano tabele Microsoft Access do pliku tekstowego; poddano plik konwersji na polskie znaki - zastosowane kodowanie ISO 8859-2; zaimportowano plik do bazy danych MySQL i zamieszczono na szybkim serwerze firmy ZIGZAG. Baza inwentarzy daje możliwość wyszukiwania według określonych kategorii (kluczowe słowa, daty itd.). 
W drugim pliku Inwentarz (baza danych) kwerendzista może zapoznać się ze spisem 162. zespołów. W każdym z nich podano numer, sygnaturę, sygnaturę jednostki, nazwę jednostki, daty skrajne, ilość stron/kart, dawną sygnaturę oraz dodatkowe uwagi. Dotąd wpisano 35 zespołów akt, które obejmują 1410 jednostek archiwalnych.

W osobnej bazie zebrano Zbiory metrykalne. Na podstronach Zbiorów metrykalnych zamieszczona jest krótka informacja o katalogu i sposobie korzystania. Objaśniono także znaki: metrykalne, chrztów (*), małżeństw (o), zgonów (+) i indeksów alfabetycznych ksiąg (i). W katalogu podano również zakres lat, sygnaturę księgi w archiwum, oraz numer mikrofilmu. Cały katalog, z uwagi na jego zasoby, podzielono na dwie części: Katalog ksiąg metrykalnych katolickich (obejmuje 341 parafii) oraz Katalog ksiag metrykalnych ewangelickich (obejmuje 32 parafie). Metryki poszczególnych parafii katolickich i ewangelickich uszeregowane zostały alfabetycznie (wedlug nazw miejscowości).

Na podstronie Biblioteki Wydziału Teologicznego UAM w Poznaniu, Oddziału Rękopisów i Starodruków kwerendzista może zapoznać się z krótką historią biblioteki, zasobami zbiorów oraz publikacjami o niej. Dalsze podstrony zawierające informacje o Rękopisach, Starodrukach i Drukach ciąłych pozostaja w trakcie obróbki.

Na stronie Archiwum Archidiecezjalnego w Poznaniu łatwo można uzyskać także informacje adresowe, godziny pracy i wykaz pracowników.

Archiwum Archidiecezjalne w Poznaniu nadal poszerza system informacyjny. Trwają bowiem prace nad komputerową bazą inwentarzy archiwum, do której sukcesywnie wpisywane są nowe zespoły. Planowane jest połączenie plików graficznych z informatorem o zasobie. Ponadto archiwum posiada już gotową bazę danych czasopism, która obejmuje 1849 tytułów. Opracowywana jest baza starodruków (3508) i inkunabułów (799).

Istnieje również gotowa baza zdjęć i albumów.

\section{Archiwum Archidiecexjalne w Gnieźnie}

Po wdrożeniu strony internetowej w Poznaniu, podobny system uruchomiono w Archiwum Archidiecezjalnym w Gnieźnie. Również tam na stronach intemetowych: www.aag.gniezno.opoka.org.pl można korzystać z zasobów archiwum w języku polskim, angielskim lub niemieckim. Na podstronach tejże instytucji można zapoznać się z historią archiwum (Archiwum), zaś na podstronie Biblioteka z historią Biblioteki Katedralnej. Znalazly się tam również szczegółowe instrukcje Zasad udostępniania, oraz dokładna Lokalizacja Archiwum (z mapką i trasą dojścia z dworca PKP) i niezbędne dane o funkcjonowaniu placówki. Podstrony mające przedstawiać spisy zespołów są w trakcie opracowania.

W Archiwum Archidiecezjalnym w Gnieźnie wykorzystuje się program księdza Czesława Pesta - TABULARIUM. 


\section{Archiwum Archidiecezjalne w Katowicach}

Swoją stronę internetową rozbudowuje także Archiwum Archidiecezjalne w Katowicach: archiwum.archidiecezjalne.katowice.opoka.org.pl. Na stronie tytułowej zostały podane informacje adresowe, zakres opieki rzeczowej pracowników i godziny przyjęć interesantów. Na podstronach zaprezentowano dzieje archiwum, regulamin (skan Regulaminu Archiwum Diecezjalnego w Katowicach podpisanego przez bp. Damiana Zimonia 3 kwietnia 1991 roku), wydawnictwa opublikowane przez pracowników archiwum, informacje o wystawach (Newsy Archiwum), spis zespołów znajdujących się w instytucji (Zasób Archiwum) wraz $\mathrm{z}$ cennikiem opłat za kwerendy genealogiczne $\mathrm{i}$ własnościowe (Kwerendy genealogiczne $i$ wtasnościowe).

\section{Archiwum Diecezjalne w Lomży}

Na stronach diecezji łomżyńskiej zamieszczono natomiast podstrony zawierające sporo informacji na temat archiwum diecezjalnego i zasobów (www.kuria.lomza.pl). Na stronie tytulowej znajdują się wejścia na kolejne podstrony archiwum. Na nich można się zapoznać z zasadami korzystania $z$ archiwum, godzinami pracy (Korzystanie z Archiwum Diecezjalnego), a dalej zamieszczono dzieje diecezji i archiwum (Archiwum Diecezjalne w Łomży), informacje o aktach parafialnych (Akta parafialne), ogólnych (Akta ogólne), zakonnych (Akta zakonne), metrykalnych (Akta metrykalne). Każda podstrona posiada informacje o ilości wejść (korzystających z zasobów).

\section{Archiwum Diecezjalne w Tarnowie}

Swoją stronę internetową posiada także Archiwum Diecezjalne w Tarnowie (www.archiwum.diecezja.tarnow.pl). Zamieszone sq na niej podstawowe informacje adresowe i godziny pracy archiwum (Wstep). Na kolejnych podstronach przedstawione zostały informacje o historii instytucji (Dzieje), spis zespołów, zasoby ksiçgozbioru podręcznego i wykaz publikacji na temat archiwum (Zasób) $\mathrm{i}$ - co oczywiste - regulamin pracowni naukowej (Regulamin).

\section{ZAKoŃCZENIE}

Rozwój nowoczesnych komputerowych systemów informacji niewątpliwie ułatwia korzystanie z zasobów archiwalnych. Dzięki komputerowi, szczególnie sieci internetowej, można szybko dotrzeć do określonych informacji, co zaoszczędza wiele czasu i pieniędzy. Jednak trwa metodyczna dyskusja jak dalece posuwać się w szerokim udostępnianiu przez Internet informacji na temat zasobów archi- 
wów. Czy tylko poprzestawać na spisach zespołów, jakie pojawiły sic̨ na stronach archiwów kościelnych w Katowicach, Tarnowie i Łomży, czy też udostępniać kwerendzistom szczegółowe informacje na temat każdej jednostki archiwalnej na swoich stronach WWW. Kwerendzista swobodnie może uzyskać informacje nie tylko o zespole w wybranym archiwum w sieci, ale także o poszczególnej jednostce archiwalnej. Padaja sugestie, że zbyt dokładne informacje i łatwy do nich dostęp zwiększa zagrożenie kradzieży na zamówienie.

Wprowadzenie do stron internetowych spisów zespołów ułatwia pracę przede wszystkim pracownikom archiwum. $Z$ pewnością zmniejsza nakład sił i środków przeznaczony na prowadzenie korespondencji z interesantami i w zasadniczy sposób zmniejsza ilość rozmów telefonicznych z osobami szukającymi niezbędnych informacji, porady i pomocy. Dzięki dostępowi do Internetu kwerendzista ( $\mathrm{z}$ dostepem do sieci) może już $w$ domu przygotować sobie dokładne dane na temat interesujących archiwaliów i z nich skorzystać.

W przyszłości szerokie wprowadzenie dostępu do informacji o zasobach poprzez Internet mogłoby także pomóc w scalaniu rozproszonych zespołów. Wówczas bez wychodzenia do archiwum łatwo byłoby sprawdzić, w której instytucji w kraju znajdują się poszukiwane akta.

Jednak jak wiadomo, wprowadzanie nowoczesnych systemów informacyjnych w najwiçkszej mierze zależne jest nie tylko od chęci i zapału archiwistów, lecz przede wszystkim od możliwości i zasobów finansowych archiwów kościelnych. 